〔専門医講習会テキストシリーズ〕

\title{
一大学病院の立場から一
}

\author{
金沢医科大学耳鼻咽喉科 \\ 鈴 鹿 有子 \\ I はじめに
}

医師不足の解決策の 1 つして女性医師の存在が重要なキーワードになってきた，そして女子医学生の加速的増加に 伴い女性医師比率も増大し，これに単を発して女性医師のさまざまな問題がクローズアップされるようになった。そこ には女性医師の活動率が低下していることも見逃せない．どんな対策が必要であるのかを知り，また学会としての対応 が可能であるのか．ここでは耳鼻咽喉科医師の現状，女性医師の実態を報告し，全体として考えるべき問題，大学病院 の立場などを述べる。

\section{II 女性医師数の推移}

日本の女性医師は年々増加し，平成 6 年総医師数約 23 万人の $12.7 \%, 29,000$ 人であったが，平成 22 年には総医師数約 29 万 5 千人の $18.9 \%$ になった。 また，女子医学生の総数は徐々に増加し，近年，国家試験の合格者の女性の比率が約 3 分の 1 になっていることで，ますます女性医師の比率は高まっていくものとみなされる． 3 人に 1 人が女性がという時 代がやってくる

\section{III 耳鼻咽喉科の現状}

日本耳鼻咽喉科学会総務部調查委員会による全国調查では，耳鼻咽喉科医師数は平成 9 年で 8,694 人，その後徐々 に増加傾向にあり，平成 24 年には耳鼻咽喉科医師は 9,920 人で昨年より 305 人増加した（図 1 )。耳鼻咽喉科女性医師の 比率も増加し $20.0 \%$ になった，新入局員に関しては，平成10年ころから減少傾向が始まり，新研修医制度で激減したあ と平成18年から数年は減少に歯止めはかかったようにみえた，しかし平成23年から再び減少傾向にあり，平成25年は前 年より男子は 5 人の増加，女子は 3 人の減少で合わせて 214 人であった（図 2 )。新人女子の 2 年連続の減少にショック を受けるとともに，男女そろっての減少傾向はカーブではなく右下がりの直線を描いてしまった（図 3 ).

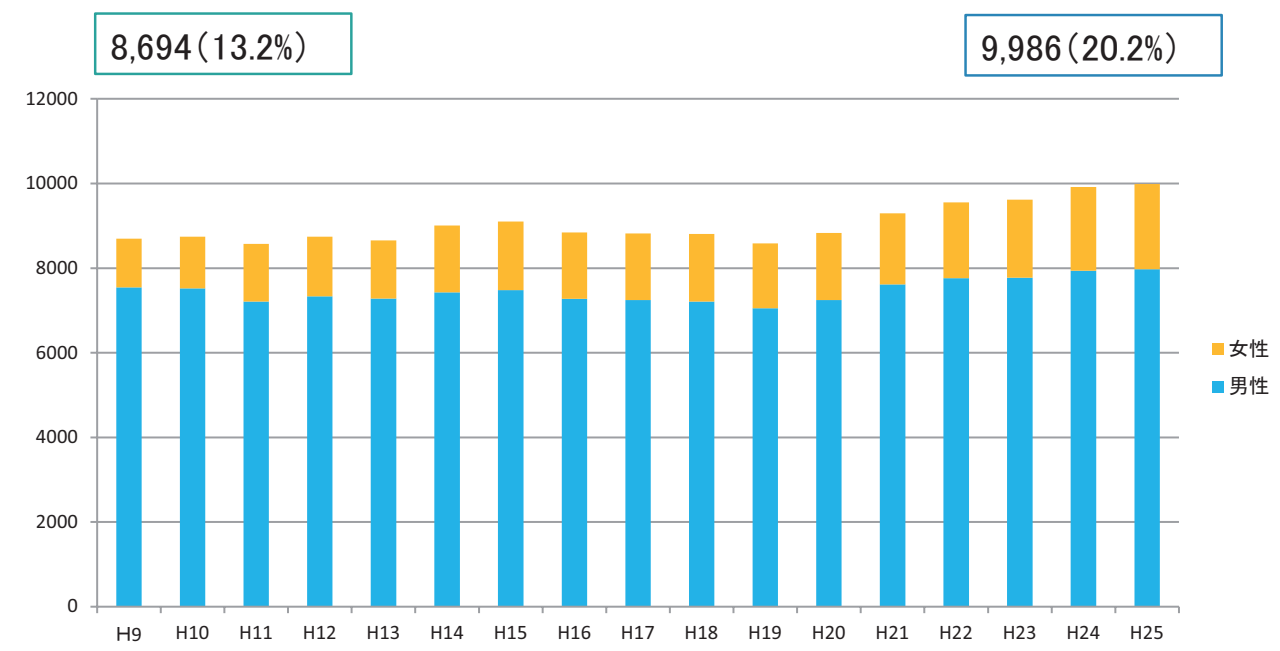

図 1 日本の耳鼻咽喉科医師数の推移 平成 9 年から平成 25 年 


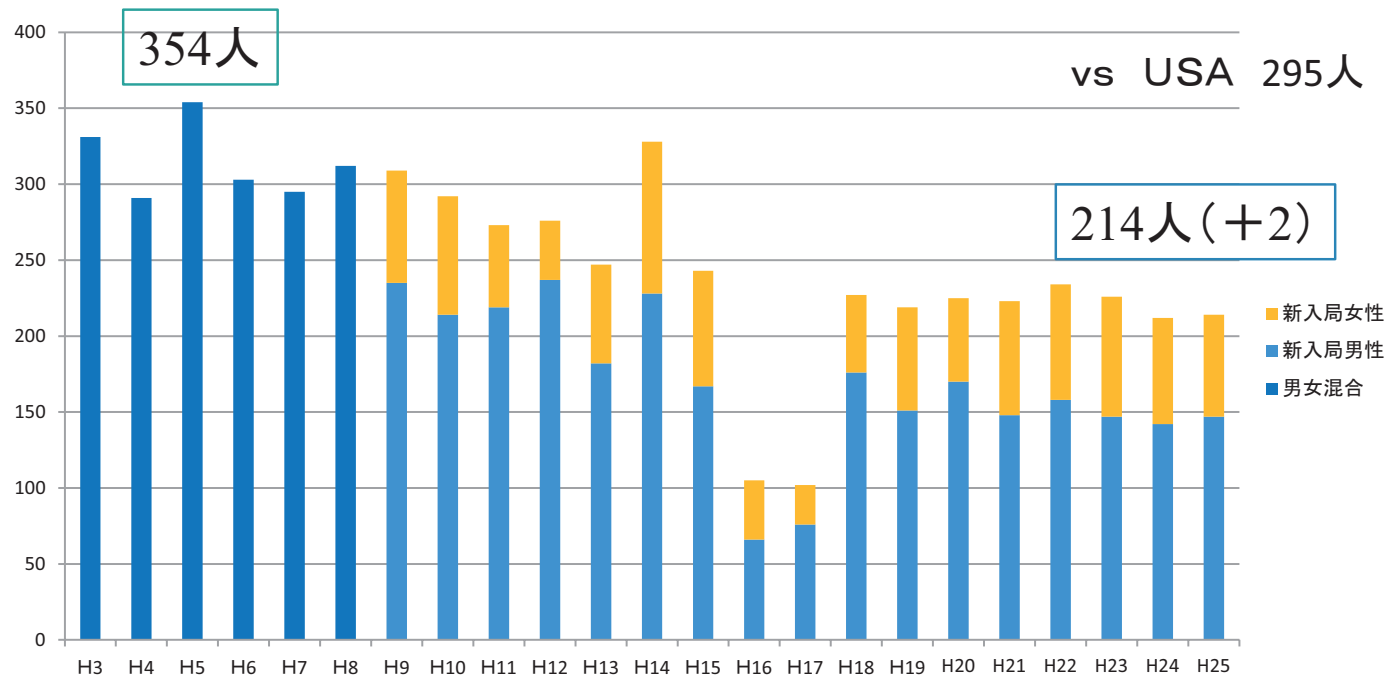

図 2 耳鼻咽喉科新入局員数の推移 平成 3 年から平成 25 年

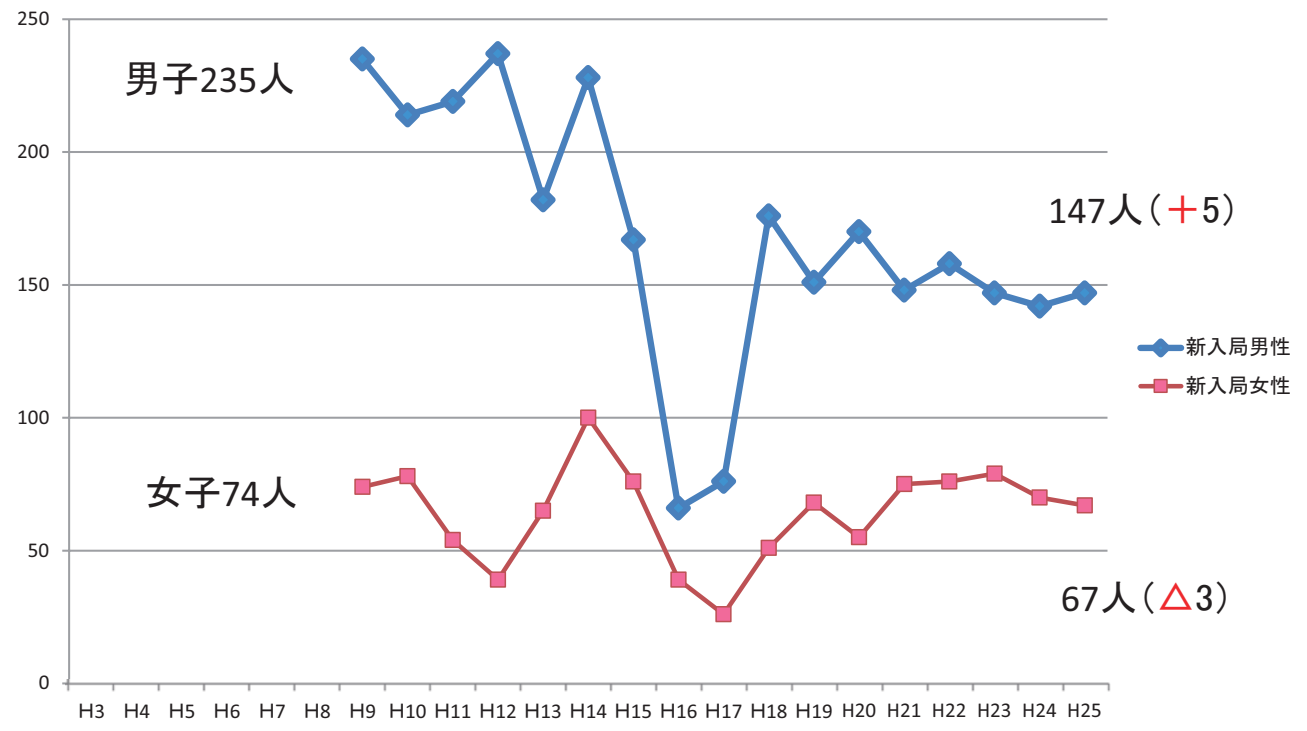

図 3 新入局員数の男女別推移 平成 9 年から平成 25 年

\section{N 日本耳鼻咽喉科学会}

学会の業務組織は理事長, 副理事長, 理事, 監事, 顧問, 幹事で構成され, 全26名で女性はいない（図 4 )。代議員 は全国で 288 人存在し，10人の女性医師が含まれる。平成 $24 \cdot 25$ 年の日耳鼻の実務には 17 委員会があり，委員は 105 名, うち女性医師は11名である (図 5 )。関連する学会・研究会の主なものは16あって, 役員は492人のうち女性は $21 人$, 全 委員数 1,254 人のうち女性は 69 人で $5.5 \%$ であった（図 6 ). 女性医師の率が $20 \%$ になった昨今, 女性の能力を再評価し ていただき，登用を考虑していただきたいと思う。

\section{$\mathrm{V}$ 大学病院の使命}

耳鼻咽喉科医の獲得が最重要課題

耳鼻咽喉科医の新人の減少は, 日本の耳鼻咽喉科学の魅力を伝えきれない大学の責任である.ずばり教育現場が興味 をそそらないことが影響する。授業もポリクリも学生には以前のように響かないのである。医局も楽しそうには見えな 
〔専門医講習会テキストシリーズ〕

\section{日本耳鼻咽喉科学会 役員数 (平成24-25年度)}

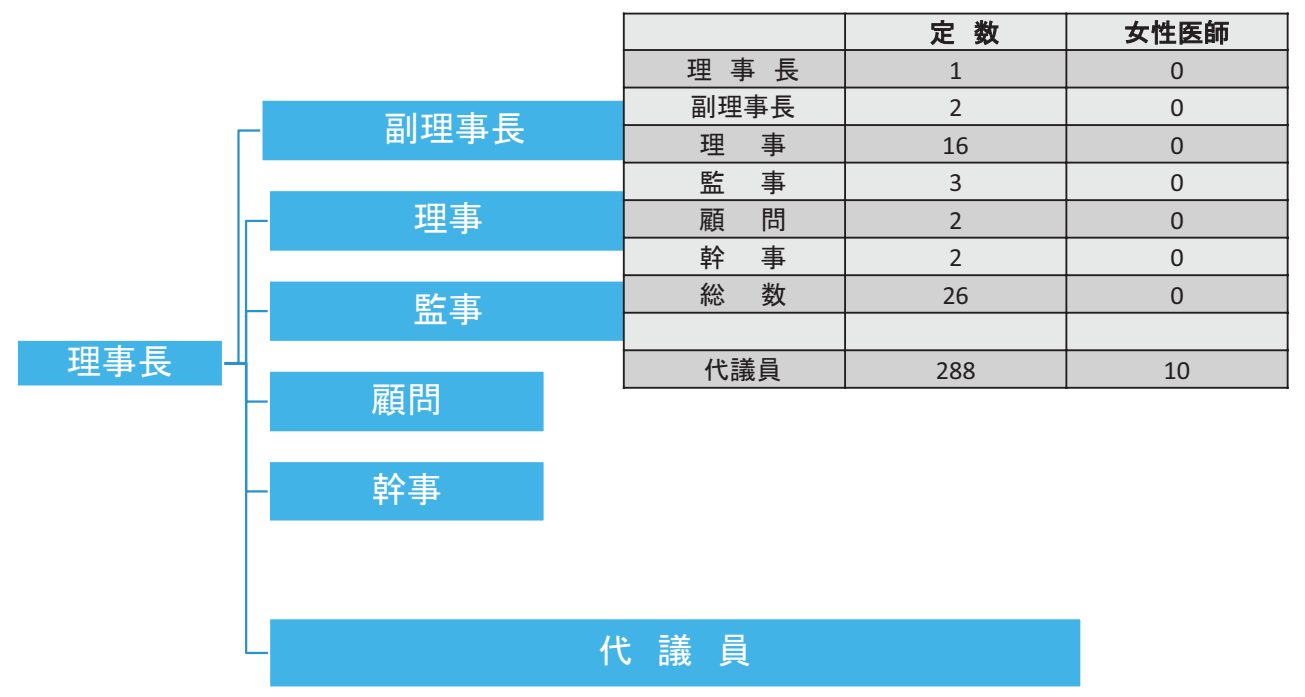

図 4 耳鼻咽喉科学会 業務組織図と人数

\section{平成24.25年度日本耳鼻咽喉科学会 委員会 (17) 構成}

\begin{tabular}{|c|c|c|c|}
\hline 委員会 & 担当理事 & 委 員 & 女性医師 \\
\hline 庶務 & 3 & 1 & 0 \\
\hline 定款 & 2 & 4 & 0 \\
\hline 調査 & 2 & 5 & 1 \\
\hline 聴·平衡·言語 & 2 & 7 & 1 \\
\hline 広報 & 2 & 5 & 0 \\
\hline 渉外 & 1 & 1 & 0 \\
\hline 経理 & 2 & 1 & 0 \\
\hline 会報編集 & 2 & 7 & 0 \\
\hline 英文誌 & 2 & 13 & 0 \\
\hline 専門医制度 & 3 & 7 & 1 \\
\hline 学術 & 2 & 8 & 0 \\
\hline 関連する学会 & 1 & 0 & 0 \\
\hline 保険医療 & 4 & 12 & 2 \\
\hline 産業·環境保健 & 2 & 5 & 0 \\
\hline 福祉医療 & 2 & 16 & 5 \\
\hline 学校保健 & 2 & 7 & 0 \\
\hline 医事問題 & 2 & 6 & 0 \\
\hline 総数 & 33 & 105 & 10 \\
\hline
\end{tabular}

図 5 学会委員会 17 と役員数

いのではないか. 学生に過剩なサービスする必要はないが, 自分がこうして選んだ耳鼻科がどうしても面白くないとは 思えないのだ。医局全体で，さらにこの点を取り組んでくれませんか. 医師を目指してその輝きを保ち続けるかどうか は，特に女子にとっては最初の数年にかかっている.

大学病院ではキャリアを重ねることができる。キャリアは医師免許証の次に大事なものである。最初は研究活動にな るが, 学会活動も優先されるし, その先には国際学会や留学等と若人には大きな夢でもある. 医局崩壊といわれている 今，秩序も権限もなく，基礎的研究に始まる科学的進歩もなく，日課を調整するただの事務所である，大学の医局とは 


\section{関連する学会·研究会 (16）（2012-13参照)}

\begin{tabular}{|l|c|c|c|c|}
\hline \multicolumn{1}{|c|}{ 学 会 } & 役 員 & 女性医師 & 評議員·委員 & 女性医師 \\
\hline 日本聴覚医学会 & 50 & 0 & 52 & 7 \\
\hline 日本めまい平衡医学会 & 22 & 1 & 55 & 3 \\
\hline 日本耳科学会 & 46 & 1 & 84 & 5 \\
\hline 日本鼻科学会 & 25 & 0 & 69 & 1 \\
\hline 日本気管食道科学会 & 57 & 0 & 154 & 3 \\
\hline 日本頭頸部癌学会 & 44 & 0 & 71 & 0 \\
\hline 日本音声言語医学会 & 45 & 11 & 80 & 20 \\
\hline 日本顔面神経研究会 & 13 & 0 & 63 & 0 \\
\hline 感染症研究会 & 18 & 0 & 98 & 4 \\
\hline 日本小児耳鼻咽喉科学会 & 24 & 6 & 63 & 17 \\
\hline 耳鼻咽喉科臨床学会 & 19 & 0 & 83 & 0 \\
\hline 免疫アレルギー学会 & 26 & 1 & 46 & 0 \\
\hline 日本口腔·咽頭科学会 & 25 & 0 & 94 & 2 \\
\hline 日本喉頭科学会 & 23 & 0 & 130 & 4 \\
\hline 日本頭頸部外科学会 & 24 & 0 & 16 & 0 \\
\hline 日本嚥下医学会 & 31 & 1 & 96 & 3 \\
\hline 総 数 & 492 & 21 & 1254 & 69 \\
\hline
\end{tabular}

図 6 関連する学会・研究会 16 と役員数

大海へ新人の第一歩をいざない，ゴールを掲げて，目標に向かう義務感を培うと同時に充実感を覚えさせ，一段一段登 らせるシステムのコントロールルームである。そしてそれは一人ではない，前にも横にも後ろにもだれかがいる，指導 者がいる，応援がいる，ライバルがいる，そんな大学に魅力を感じない者はいない，

\section{VI 女子が大学病院に求めること}

最近のアンケートで女性医師が大学病院に臨むことの第一は産休・育休の延長や保育施設の充実ではなく, 勤務条件 の緩和である。つまり休みたいのではなく，働きたいし，続けたいのである.

女性医師の勤務形態が明らかになった，女性医師に扔ける常勤医師と非常勤医師の比率は，国立大学で $1 ： 2$, 公 立大学 $1: 1.2$, 私立大学 1：0.8で国立が最も非常勤の比率が高い. 短時間の正規雇用, フレックスタイムなど組み 合わせて勤務制度の柔軟化し，育児中はしばらくは非常勤を選択してでも，とにかくキャリアを継続，再び常勤へ移行 するなど自由に選べる体制の完備と，それを受け入れる体制が必須である.

VII おりに

人間は異性と働くことで男性，女性ともに特性が生かされてくる。また仕事の能率や正確度の上昇においても個人よ りは複数, 単一の性より混合と, 違いが出ることは科学的にも証明されていて，スペースシャトルのクルー構成がそう である。ここに女性医師の存在をあらためて理解していただき，活躍できるような環境に改善することは，男性医療人 にとっても働きやすい職場環境を獲得することでもある，男女共同して，耳鼻咽喉科のよりよい医療をすすめることが できることは，皆の願いである．

P.S. 朗報 日本耳鼻咽喉科学会に男女共同参画委員会が発足します。 